\title{
Short-temporal variation of soil organic carbon in different land use systems in the Ramsar site 2027 'Presa Manuel Ávila Camacho' Puebla
}

\author{
L C López-Teloxa ${ }^{1}$, A Cruz-Montalvo ${ }^{2}$, J V Tamaríz-Flores ${ }^{1,2}$, \\ R PÉrez-Avilés ${ }^{1,3}$, E Torres $^{1}$ and R CAstelán-VegA ${ }^{1,2, *}$ \\ ${ }^{1}$ Posgrado en Ciencias Ambientales, Instituto de Ciencias, Benemérita Universidad Autónoma de Puebla, Edificio \\ IC 1 Ciudad Universitaria, Puebla C. P. 72570, Mexico. \\ ${ }^{2}$ Departamento de Investigación en Ciencias Agrícolas, Puebla, Mexico. \\ ${ }^{3}$ Departamento Universitario para el Desarrollo Sustentable, Puebla, Mexico. \\ ${ }^{*}$ Corresponding author.e-mail: rosalia.castelan@correo.buap.mx
}

MS received 18 August 2016; revised 31 March 2017; accepted 4 May 2017; published online 6 October 2017

The soil organic carbon (SOC) was determined in 40 sites at two depths (0-10 and 10-20 cm) for different uses of soil during one year (February 2014-February 2015). The total SOC stored in the analysed soil from the Ramsar site was $9,67 \times 10^{5} \mathrm{t}$, from which $40 \%$ was stored in induced pasture, followed by the red oak forest with shrubbery secondary vegetation, rain-fed agriculture and human settlements $(24 \%, 23 \%$, and $13 \%$, respectively); the last was evaluated to determine how the proximity of the city impacts the SOC. The SOC concentrations present significant differences with respect to soil depth $(p=0.0)$ and land use $(p=0.0)$. The temporal distribution maps showed that SOC did not present significant variations in the short-term. A relation between SOC and bulk density was found $(r=-0.654, p=0.00)$, with respect to other physicochemical properties. Moreover, a significant relation between SOC and stored total nitrogen $(r=0.585 ; p=0.00)$ was found. This work represents the first study that analyses the current condition of the soils in the Ramsar site 'Presa Manuel Ávila Camacho'.

Keywords. Soil organic carbon (SOC); Ramsar site; spatial maps.

\section{Introduction}

There is growing public and scientific concern regarding the potential carbon sequestration of the terrestrial ecosystems, as carbon dioxide $\left(\mathrm{CO}_{2}\right)$ emissions into the atmosphere have increased in recent years, mainly due to anthropogenic activities (Singh et al. 2015). One of the most important elements to lessen atmospheric $\mathrm{CO}_{2}$ is the soil, given that it can act as an important $\mathrm{CO}_{2}$ pool, which contributes significantly in reaching the levels committed to in the Kyoto Protocol regarding the stabilization of the $\mathrm{CO}_{2}$ atmospheric concentration (Huang et al. 2016). The soil's capacity for carbon sequestration varies in accordance with the soil type and its physicochemical characteristics, management, and environmental factors (McGrath and Zhang 2003; Singh et al. 2015). The manipulation of some factors, especially those related to the management, can be used to keep or enhance the content of soil organic carbon (SOC) (McGrath and Zhang 2003). Therefore, in order 
to mitigate the effects that cause the increase in the $\mathrm{CO}_{2}$ concentration in the atmosphere, it is necessary to carry out practices that increase the production of vegetal biomass or that reduce erosion, both of which are effective in improving carbon sequestration. This challenge can be tackled only through the implementation of new soil usage alternatives. It is well known that flooded soils, which are characteristic of wetlands, are an important reservoir of organic carbon (Bao et al. 2011; Yu et al. 2012; Pal et al. 2016). However, it is also considered important to know the conditions of the soil that surround the wetlands to contribute to their conservation and to promote their management and payment of environmental services. It is also known that the soils are capable of annually storing $10 \%$ of the annual $\mathrm{CO}_{2}$ emissions (Yadav et al. 2009). Soils naturally contain $3150 \mathrm{Pg}$ C stored, four times more than that stored in the vegetation (650 Pg C) (Hobley et al. 2016; Assefa et al. 2017). Thus, it is important to know the current state of a site from a spatial and temporal way to contribute on the application of tools as conservation, adaptation and reduction of climate change policy (Jones et al. 2017; Sayoud et al. 2017).

Ramsar convention is an inter-governmental treaty adopted on February 2, 1971, in the Iranian city of Ramsar, for conservation and sustainable use of wetlands (Ramsar Convention Secretariat 2013). To attain the objectives of the convention, it is necessary to first evaluate the space-temporal variation of the vegetation coverage, the land use change and the content of organic carbon in different sites of the Ramsar (Juman and Ramsewak 2013; Mabwoga and Thukral 2014; Pal et al. 2014, 2016). The principal results reveal that the natural vegetation of the sites has decreased mainly due to human activities, agricultural growth and climate change, and yet, despite these conditions the wetlands are highly capable of storing organic carbon. Hence, research in the field is important, as it takes the appropriate measures that slow down higher degradation extents. However, this research is the first study related to the Ramsar site 2027 'Presa Manuel Ávila Camacho' that may be taken as a starting point for future temporal and space studies that relate to their capacity of storing carbon.

The Ramsar site 'Presa Manuel Ávila Camacho' is located in the State of Puebla, México, specifically in the southern part of the valley of Puebla, and is characterized for accommodating
231 species of birds, of which 16 have a protected status (12 of special protection and four endangered species) (CIIEMAD 2011). Furthermore, there are 10 species of endangered aquatic flora, and the terrestrial vegetation includes mainly pastures/agriculture, oak forests, tropical deciduous forests, and palm grove forests (CIIEMAD 2011). However, in spite of its importance as a carbon pool of Ramsar sites, to the best of our knowledge there have been no studies conducted so far regarding the capacity of the soil from Ramsar site 2027 to store carbon. Therefore, the purpose of this study was to evaluate the spatial and short-temporal variation of SOC, pH, soil total nitrogen (STN) and bulk density (BD) in the Ramsar site 2027 'Presa Manuel Ávila Camacho' in order to provide the status of its carbon stored, and the effect of different physical and chemical parameters, with seasons of the year and land uses.

\section{Materials and methods}

\subsection{Characteristics of the site}

Ramsar site 2027 covers 23,612 ha in the southern part of the municipality of Puebla, México (figure 1), in the Cuenca del Alto Balsas and includes an alluvial valley formed by the Atoyac river, the 'Presa Manuel Ávila Camacho' (Valsequillo Dam), which is the largest permanent body of water in the state of Puebla occupying 2832 ha, and the forested areas of the Sierra del Tentzo. Likewise, Valsequillo is part of the bird migration corridor of America. The types of soil in the site include: Phaeozems (east and west of the Dam), Regosols (west of the Dam), Cambisols (southeast of the Dam), Lithosols (south and south-west of the Dam), Rendzinas (south and south-west of the Dam), and Vertisols (north of the Dam). The highest part is located in the southern part of the site where there are slopes greater than $30^{\circ}$ (CIIEMAD 2011). The annual precipitation in the site varies between 741 and $863 \mathrm{~mm}$. The average annual temperature in the site varies between $16^{\circ}$ and $17.5^{\circ} \mathrm{C}$.

\subsection{Soil sampling and analysis}

According to the vegetation type map of the cartography of the National Institute of Statistics and Geography series V, which corresponds to the vegetation of 2013, a total of 40 points were selected for the sampling in soils of the Ramsar 


\section{Site location "Presa Manuel Ávila Camacho"}

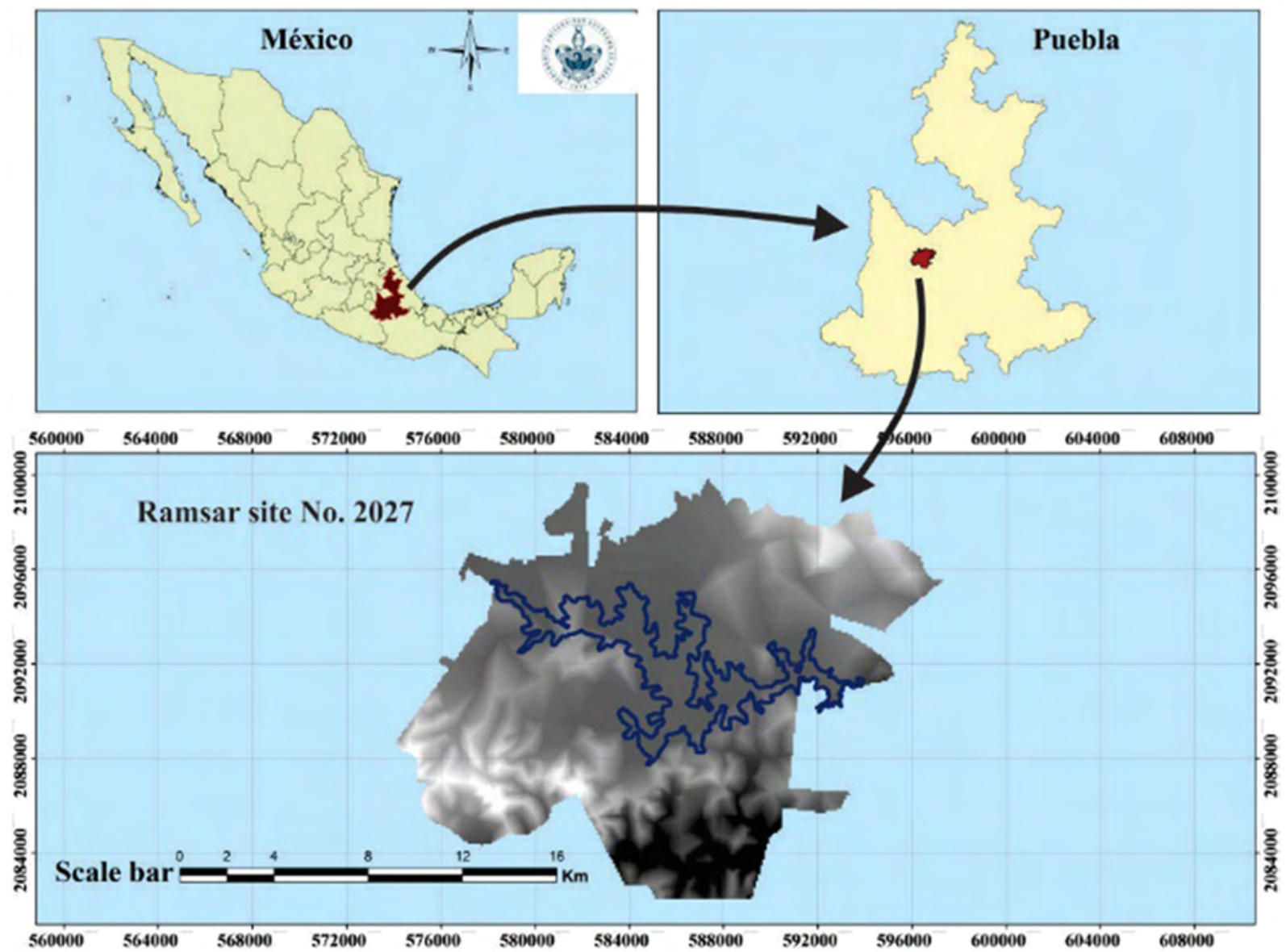

Figure 1. Geographical location of the study area Ramsar site 'Presa Manuel Ávila Camacho' (Puebla, Mexico).

site; it is worth mentioning that this selection was also done considering the access to the area. A portable global positioning system (GPS) was used to record each sample site (figure 2). As reported, climatic conditions of each season of the year may have an effect on soil organic carbon content (Pal et al. 2014; Assefa et al. 2017). Therefore, two sampling periods were carried out in 2014, the first (Dry 1) being carried out in February, with no record of precipitation and a reported temperature of $15.9^{\circ} \mathrm{C}$; the second (Rainy) was carried out in July, with $78.9 \mathrm{~mm}$ of rain and a temperature of $17.75^{\circ} \mathrm{C}$; the third sampling (Dry 2) was carried out in February 2015, with $1.6 \mathrm{~mm}$ of rain and a temperature of $14.8^{\circ} \mathrm{C}$. Each sample was composed of one kilogram of soil from a depth of $0-10$ and $10-20 \mathrm{~cm}$. A total of 240 samples were collected, including the four types of land use in the Ramsar site: rain-fed agriculture (RA, 84 samples, 5575 ha), induced pasture
(IP, 90 samples, 7207 ha), human settlements (HS, 30 samples, $4487 \mathrm{ha}$ ), and oak forest with shrubbery secondary vegetation (OF/sSV, 36 samples, $4115 \mathrm{ha}$ ). The cylinder technique was employed in order to determine the bulk density in accordance with Blake et al. (1986). The collected samples were dried at room temperature and sieved with a $1.73 \mathrm{~mm}$ sieve. Then, the percentage of organic carbon was determined through the Walkley-Black method; the percentage of total nitrogen was determined through the micro-Kjeldahl method and the $\mathrm{pH}$ values were determined using a $\mathrm{pH}$-meter (conductronic $\mathrm{pH}$ ).

The SOC density and SOC storage were calculated using equations (1 and 2), respectively and the STN density and STN storage was calculated with equations (3 and 4), respectively.

$$
\begin{aligned}
& \text { SOC density }=C O \times B D \times H \\
& \text { SOC storage }=\text { SOC density } \times A
\end{aligned}
$$




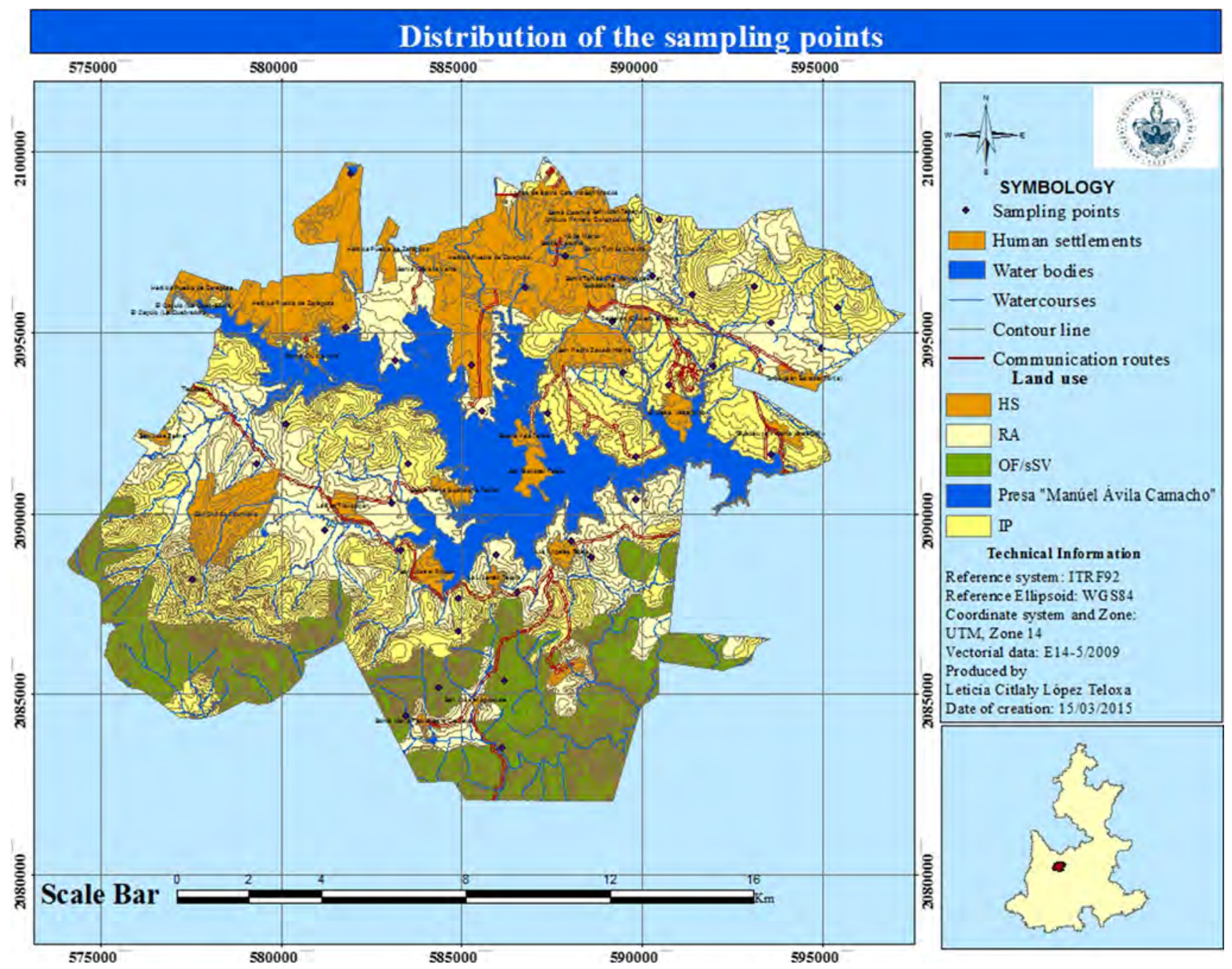

Figure 2. Distribution map of the different land uses and sampling points of the Ramsar site 2027.

$$
\begin{aligned}
& \mathrm{STN} \text { density }=T N \times B D \times H \\
& \mathrm{STN} \text { storage }=\mathrm{STN} \text { density } \times A
\end{aligned}
$$

where SOC density is soil organic carbon density (t/ha), $C O$ is the percentage of certain organic carbon in the samples, $B D$ is soil bulk density $\left(\mathrm{t} / \mathrm{m}^{3}\right)$, $H$ is the depth of the soil layer $(\mathrm{m})$, SOC storage is soil organic carbon storage (t), $A$ is the area of the different land uses (ha), STN density is the soil total nitrogen density (t/ha), $T N$ is the percentage of total nitrogen, STN storage is soil total nitrogen storage $(\mathrm{t})$.

\subsection{Generation of spatial distribution maps}

Spatial variability of SOC on Ramsar site 2027 was mapped by kriging interpolation method using Surfer 7.0, according to the measuring data of organic carbon concentration and coordinates of each sample site.

\subsection{Analysis of the dynamics of land use change in the Ramsar site 2027}

The cartography to analyse the vegetation coverage and the land use change was taken from official data in the Mexican government (Instituto Nacional de Estadística, Geografía e Informática 1976-2013). The maps for spatial and temporal distribution of land use were generated using the Arc View 3.2a software. Table 1 presents the classification system used, as well as the different types of vegetation and land use.

\subsection{Statistical analysis}

Analysis of variance (ANOVAs) was used to identify statistically significant differences in SOC, $\mathrm{STN}, \mathrm{BD}$, and $\mathrm{pH}$ values among the four land uses and two soil depths. Significant differences between the means among the four land uses and 
Table 1. Hierarchic legend of the land use (1976-2013).

\begin{tabular}{ll}
\hline Types of vegetation and land use & Code \\
\hline Red oak forest & OF \\
Red oak forest with shrubbery secondary vegetation & OF/sSV \\
Induced pasture & IP \\
Rainfed agriculture & RA \\
Water bodies & WB \\
Human settlements & HS \\
\hline
\end{tabular}

Table 2. Descriptive statistics of the physico-chemical parameters (SOC, STN, pH and DB) of the Ramsar site 'Presa Manuel Ávila Camacho'.

\begin{tabular}{lccccc}
\hline Variable & Average & St. dev. & Coef. var. (\%) & Minimum & Maximum \\
\hline SOC (t/ha) & 20.36 & 11.02 & 54.13 & 0.34 & 57.66 \\
STN (t/ha) & 1.67 & 1.14 & 68.37 & 0.04 & 5.96 \\
pH & 6.56 & 0.70 & 10.74 & 3.92 & 7.98 \\
Bulk density (BD) $\left(\mathrm{g} / \mathrm{cm}^{3}\right)$ & 1.06 & 0.11 & 10.50 & 0.70 & 1.55
\end{tabular}

Table 3. Dynamics of the land use change, 1976-2013.

\begin{tabular}{lcccccc}
\hline & \multicolumn{5}{c}{ Surface (ha) } \\
\cline { 2 - 6 } Land use & 1976 & 1993 & 2000 & 2003 & 2010 & 2013 \\
\hline OF & 356 & 95 & 341 & 0 & 0 & 0 \\
OF/sSV & 4810 & 4834 & 3762 & 4044 & 4249 & 4015 \\
WB & 2659 & 2496 & 2573 & 2569 & 2575 & 2559 \\
IP & 6173 & 6133 & 4626 & 7853 & 7089 & 7107 \\
RA & 9373 & 7468 & 9756 & 6516 & 5599 & 5475 \\
HS & 241 & 2586 & 2554 & 2630 & 4100 & 4456 \\
Total & 23,612 & 23,612 & 23,612 & 23,612 & 23,612 & 23,612 \\
\hline
\end{tabular}

two soil depths were identified by the Tukey test at $P<0.05$. All statistical analyses were performed using Minitab ${ }^{\circledR}$ 16.1.0. statistical software.

\section{Results}

\subsection{Site characterization}

In general, the SOC and STN values of soils found from Ramsar site 2027 is as shown in table 2. The content of SOC in the study area varies from 0.34 to $57.66 \mathrm{t} / \mathrm{ha}$ with a mean value of $20.36 \mathrm{t} / \mathrm{ha} \pm 11.2$; whereas, the STN varies from 0.04 to $5.96 \mathrm{t} / \mathrm{ha}$ with a mean value of $1.67 \mathrm{t} / \mathrm{ha} \pm 1.14$. In the case of $\mathrm{pH}$, it varies from 3.92 to 7.98 with a mean value of $6.56 \pm 0.70$. Bulk varies from 0.70 to $1.55 \mathrm{~g} / \mathrm{cm}^{3}$ with a mean value of $1.03 \mathrm{~g} / \mathrm{cm}^{3} \pm 0.11$; these low values of bulk density may be due the high organic matter content or high soil porosity (Curtis and Post 1964; Tanveera et al. 2016).
The natural vegetation of the Ramsar site 2027 has experienced substantial changes (table 3); according to the found data, in 1976 there were 356 ha of red oak woods (OF); however, by the year 2003 they had completely disappeared. On the other hand, a decrease of the 810 ha of $\mathrm{OF} / \mathrm{sSV}$ was observed from 1976 to 2013. Rain-fed agriculture has varied in an important way; in 1976, it covered $37 \%$ of the surface and in 2000 it increased by $3 \%$, which coincided with the period of agrarian reform and with the date when the North American Free Trade Agreement (NAFTA) became effective. Nevertheless, it drastically decreased to $23 \%$ in 2013. Another point of concern is the important growth of human settlements, which increased its surface from $1 \%$ in 1976 to $19 \%$ in 2013.

Figure 3 shows the values obtained for SOC for all sites analysed during the three sample periods (Dry 1, Dry 2 and Rainy) at both depths (0-10 and 10-20 cm); it was important to determine these 


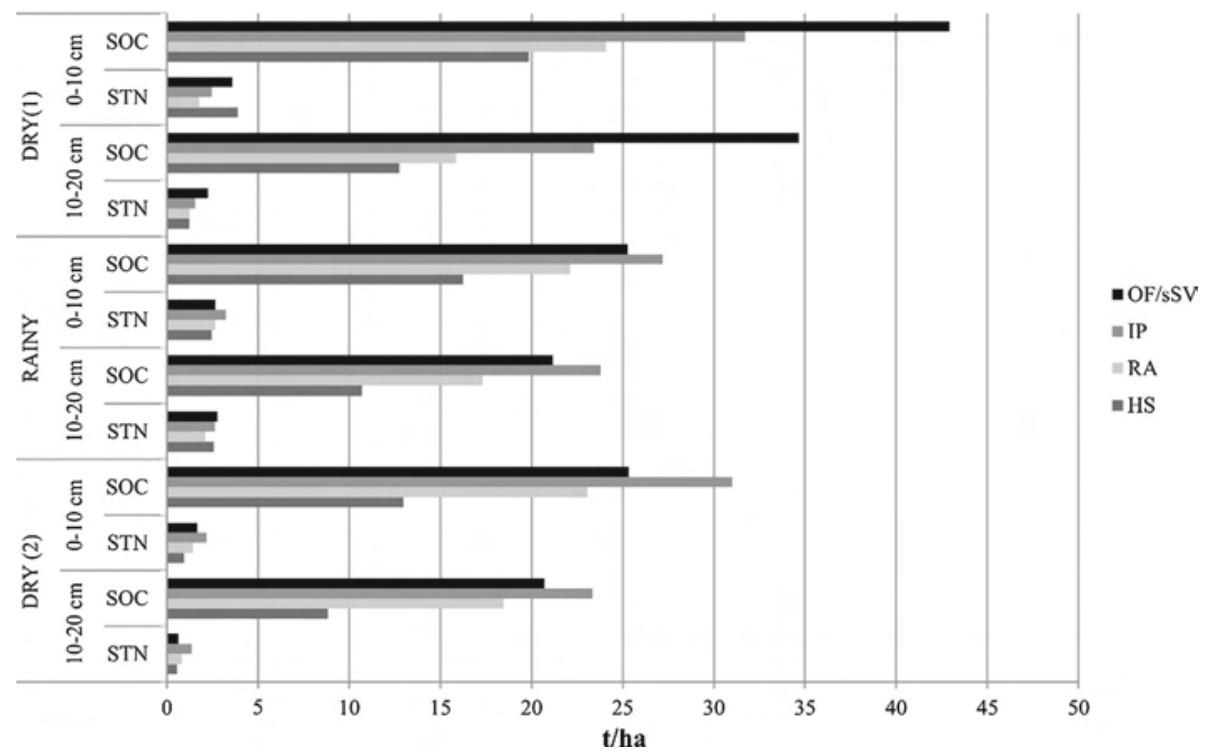

Figure 3. Average concentration of SOC and STN (t/ha) for the three sampling seasons at both depths. Note: Dry(1) $=$ Sample 1, Rainy $=$ Sample 2, Dry $(2)=$ Sample 3, SOC $=$ soil organic carbon, SNT = soil total nitrogen, rain-fed agriculture (RA), induced pasture (IP), human settlements (HS), and oak forest with shrubbery secondary vegetation $(\mathrm{OF} / \mathrm{sSV})$.

values since it is well known that the climate conditions of each season have an effect in the content of organic carbon (Pal et al. 2014; Assefa et al. 2017). In the Dry 1 period, for both depths, it was observed that the land uses with highest content of SOC were of the type OF/sSV followed by IP, whereas the lowest values were those found for HS. SOC values ranged from 43 to $19.8 \mathrm{t} /$ ha for $0-10$ $\mathrm{cm}$ soil layer; meanwhile, lower values were found, as expected, for the second layer $(10-20 \mathrm{~cm})$, which ranged from 35 to $13 \mathrm{t} / \mathrm{ha}$. STN values for the first soil layer showed an average value of $2.9 \mathrm{t} / \mathrm{ha}$, higher than the second layer $(1.6 \mathrm{t} / \mathrm{ha})$; as it is already known, the soil's depth plays an important role in the SOC and STN values, where, greater the depth, lower the SOC and STN values (Marques et al. 2015; Hobley and Wilson 2016).

For the Rainy and Dry 2 seasons, the results showed a similar pattern to that of the Dry 1 season. As it can be seen in figure 3, these seasons exhibited the highest values of SOC and STN for IP and OF/sSV land uses; however, unlike the Dry 1 season, IP showed the highest values for both parameters at both depths. In addition, SOC values for Dry 2 and Rainy seasons showed a pronounced decrease for $\mathrm{OF} / \mathrm{sSV}$ land uses compared to Dry 1 season (figure 3 ), which could indicate a higher sensitivity of $\mathrm{OF} / \mathrm{sSV}$ to climatic variations. Effectively, Dry 1 samples were collected in February, where the lack of rain, lower temperature and humidity of the soil could favour the accumulation of humus, increasing the SOC; the following sample period (Rainy), which was carried out in July, after frequent and abundant precipitation, showed a loss of accumulated SOC due to higher biological activity and also, there is a higher runoff during this season. Figure 4 shows the distribution of SOC for the three sampling periods at soil layers. As it can be observed in the Dry 1 season, at both soil depths, the SOC values are higher in the southern part of the study area (up to $70 \mathrm{t} / \mathrm{ha}$ ), where $\mathrm{OF} / \mathrm{sSV}$ land uses are found, being the furthest from the urban zone and of difficult access. On the other hand, in the Rainy season a pronounced change in SOC was observed. Highest SOC values were determined in first soil layer of the north section (up to $55 \mathrm{t} / \mathrm{ha}$ ), where IP area is found; and the lowest values from the second soil layer in the same area $(10-20 \mathrm{~cm})$. Finally, in the Dry 2 season, high concentrations of SOC were observed in the north, where the RA and IP areas are located, and also in the south, where the OF/sSV soils are found (up to $55 \mathrm{t} / \mathrm{ha})$.

\subsection{Statistical analysis}

Table 4 summarizes the SOC, STN, the $\mathrm{pH}$ and bulk density average values by sampling season 

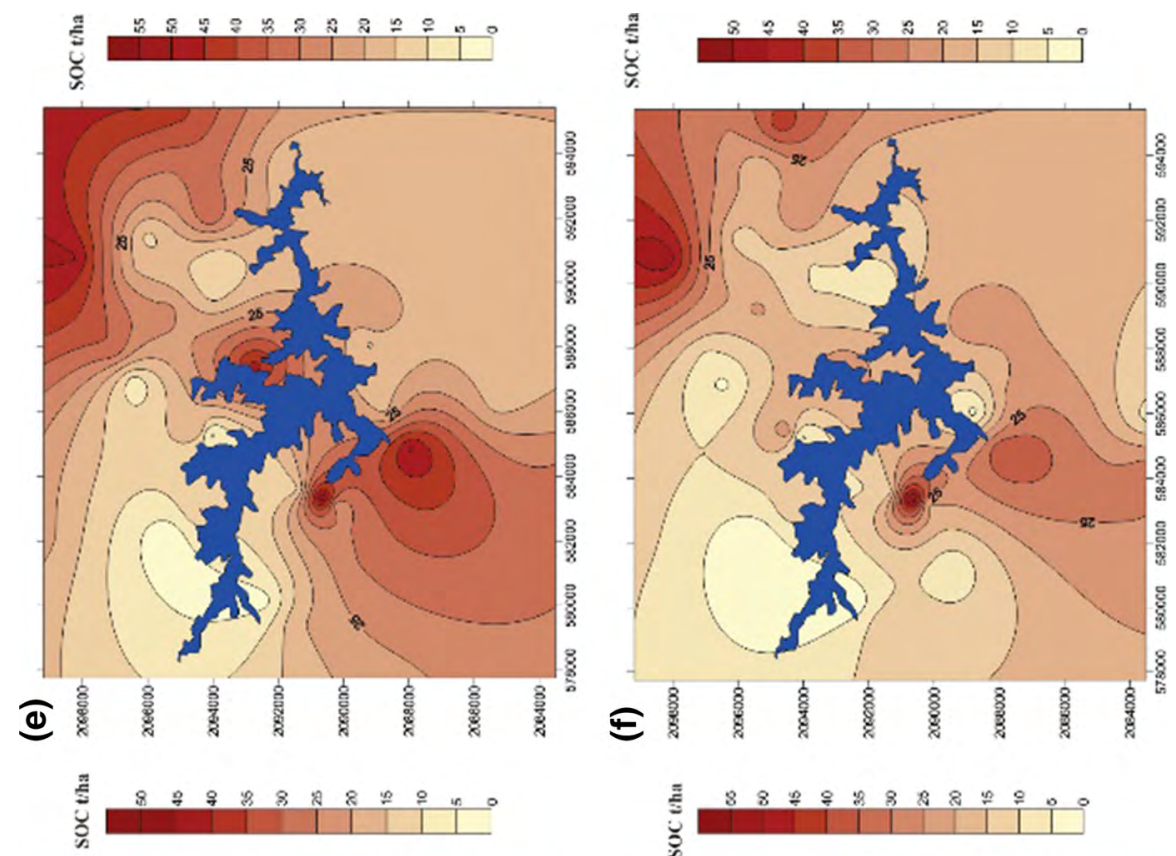

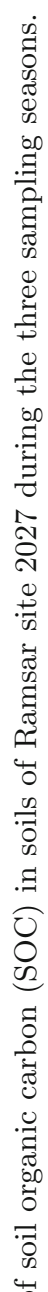
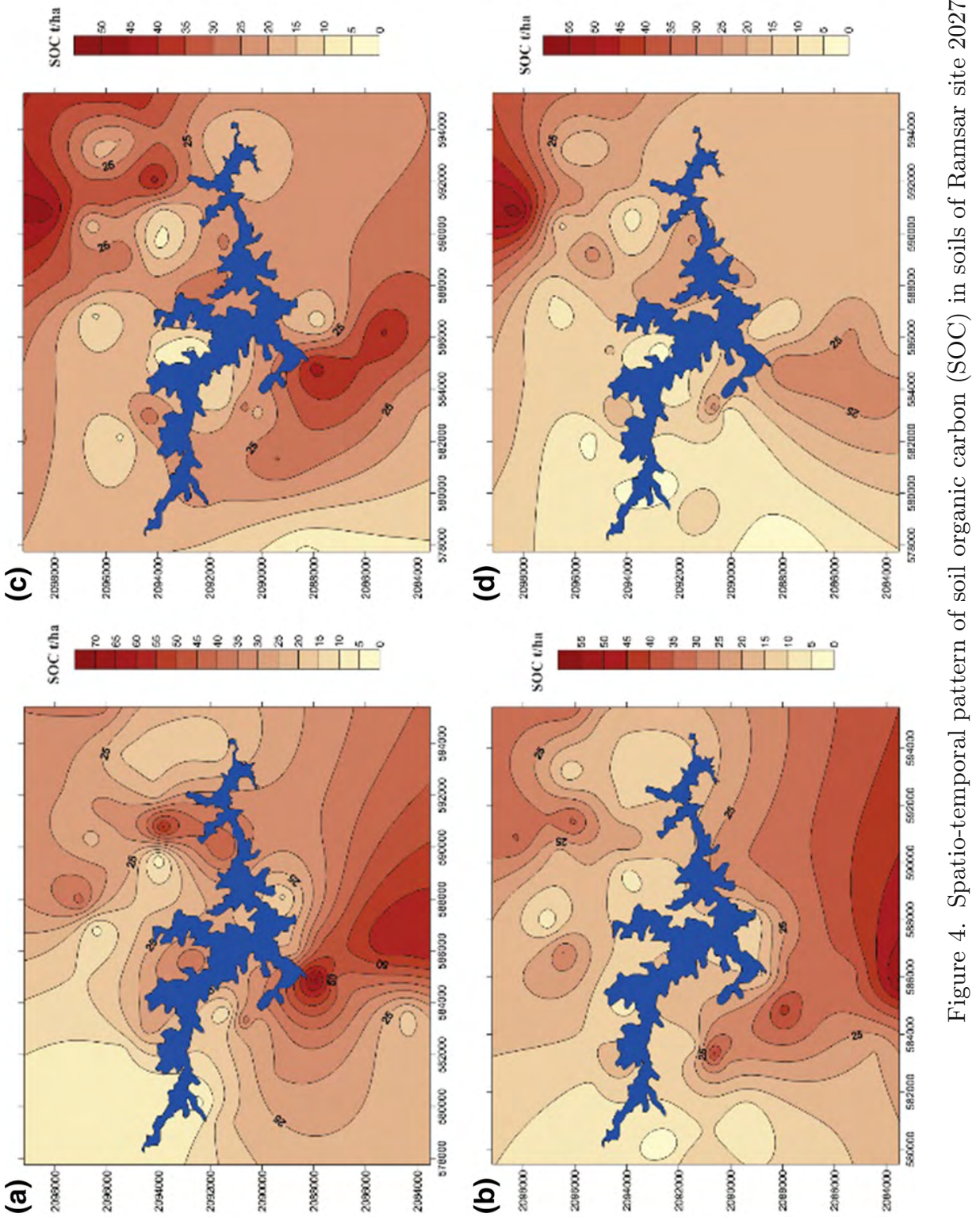
Table 4. Average results obtained for the variables SOC, STN, pH, and bulk density.

\begin{tabular}{lcccc}
\hline & \multicolumn{4}{c}{ Variable } \\
\cline { 2 - 5 } Factor & SOC (t/ha) & STN (t/ha) & pH & $\begin{array}{c}\text { Bulk density } \\
\left(\mathrm{g} / \mathrm{cm}^{3}\right)\end{array}$ \\
\hline Season & & & \\
$\quad$ Dry 1 & $25.16 \pm 15.5 \mathrm{a}$ & $2.05 \pm 1.73 \mathrm{a}$ & $6.54 \pm 0.66 \mathrm{a}$ & $1.05 \pm 0.13 \mathrm{a}$ \\
Rainy & $21.29 \pm 11.08 \mathrm{a}$ & $2.82 \pm 1.15 \mathrm{~b}$ & $6.82 \pm 0.74 \mathrm{~b}$ & $1.07 \pm 0.08 \mathrm{a}$ \\
Dry 2 & $21.91 \pm 13.24 \mathrm{a}$ & $1.31 \pm 1.07 \mathrm{c}$ & $6.37 \pm 0.63 \mathrm{a}$ & $1.06 \pm 0.10 \mathrm{a}$ \\
Depth & & & & \\
0-10 cm & $25.85 \pm 13.82 \mathrm{a}$ & $2.36 \pm 1.62 \mathrm{a}$ & $6.56 \pm 0.69 \mathrm{a}$ & $1.04 \pm 0.11 \mathrm{a}$ \\
10-20 cm & $19.85 \pm 11.68 \mathrm{~b}$ & $1.76 \pm 1.28 \mathrm{~b}$ & $6.59 \pm 0.71 \mathrm{a}$ & $1.09 \pm 0.10 \mathrm{~b}$ \\
Land use & & & & \\
OF/sSV & $28.44 \pm 13.08 \mathrm{a}$ & $2.26 \pm 1.25 \mathrm{a}$ & $6.40 \pm 0.67 \mathrm{a}$ & $1.05 \pm 0.11 \mathrm{a}$ \\
IP & $26.77 \pm 14.97 \mathrm{a}$ & $2.29 \pm 1.38 \mathrm{a}$ & $6.51 \pm 0.78 \mathrm{a}$ & $1.05 \pm 0.10 \mathrm{a}$ \\
RA & $20.42 \pm 8.42 \mathrm{~b}$ & $1.77 \pm 1.29 \mathrm{a}$ & $6.62 \pm 0.63 \mathrm{a}$ & $1.09 \pm 0.87 \mathrm{a}$ \\
HS & $13.67 \pm 10.42 \mathrm{c}$ & $1.91 \pm 2.11 \mathrm{a}$ & $6.78 \pm 0.63 \mathrm{a}$ & $1.07 \pm 0.14 \mathrm{a}$ \\
\hline Point & & & \\
\end{tabular}

Points a, b, and c indicate significant differences (Tukey test).

Table 5. Resulting $p$ values of the multivariate analysis of variance at a confidence level of $95 \%$.

\begin{tabular}{lcccc}
\hline & \multicolumn{4}{c}{ Variable } \\
\cline { 2 - 5 } Factor & SOC & STN & pH & $\begin{array}{c}\text { Bulk } \\
\text { density }\end{array}$ \\
\hline Season & 0.25 & 0.00 & 0.00 & 0.27 \\
Depth & 0.00 & 0.00 & 0.55 & 0.00 \\
Land use & 0.00 & 0.00 & 0.10 & 0.09 \\
Season $\times$ Depth & 0.81 & 0.28 & 0.65 & 0.35 \\
Season $\times$ Land use & 0.74 & 0.77 & 0.72 & 0.85 \\
Depth $\times$ Land use & 0.97 & 0.75 & 0.83 & 0.95 \\
\hline
\end{tabular}

(Dry 1, Rainy, and Dry 2), depth (0-10 and 10$20 \mathrm{~cm}$ ), and land uses (RA, IP, OF/sSV, and HS). ANOVAs were performed following the three factors of sampling protocol to determine the variability of soil parameters between factors (season, depths, and land use) of the site considered (table 5). For SOC values, no statistical differences were observed according to sampling seasons $(p=$ $0.25)$, in spite of the fact that the environmental conditions such as temperature and precipitation normally hold a dominant influence on the quantity of SOC found in the soil (Pal et al. 2014; Assefa et al. 2017). However, soil depth and land use have a significant effect on the SOC values $(p<0.05)$. On the other hand, significant differences were observed for the STN values according to sampling season, soil depth and land use $(p<0.05)$. As can be seen, in the different sampling seasons and land use, there are no significant effects in the $\mathrm{BD}$ values ( $p=0.27$ and 0.09 , respectively). Significant differences were observed only for BD according to the soil depths $(p=0.00)$. In the case of the $\mathrm{pH}$, the average was similar in both Dry seasons, but statistically different from the Rainy season $(p<0.05)$.

No effects of the interactions between season*depth, season*land use or depth*land use were observed for any of the physicochemical parameters ( $p$ values $>0.05$, table 5$)$. In other words, the combination of those factors do not influence the content of SOC. This analysis was performed to try to explain the influence of the different variables on SOC and SNT (Aliat et al. 2016; Hobley and Wilson 2016), i.e., to know how SOC varies with not only one variable but with the combination of them, so that the variation could be explained and to eventually propose a measure to increase its content.

The quantity of organic carbon that a type of soil can sequestrate is a function of its physicochemical characteristics, as well as the use and management of the soil (Robert 2002). A Pearson correlation analysis was carried out between the determined physicochemical properties in order to find out existing relation between them (table 6 ). According to the analysis, there is a strong and significant negative correlation between SOC and $\mathrm{BD}(r=-0.654, p=0.00)$; in addition, there is a positive significant correlation between the content of SOC and STN $(r=0.585 ; p=0.00)$, i.e., at a greater concentration of organic carbon, greater the content of total nitrogen; furthermore, there are other minor, although significant, correlations between SOC with $\mathrm{pH}$, as well as between STN with BD (table 6) and these correlations have been 
Table 6. Correlation tests between SOC, STN, pH, and $B D$ variables measured in soils from Ramsar site 2027.

\begin{tabular}{lccc}
\hline & SOC & STN & $\mathrm{pH}$ \\
\hline STN & 0.58 & & \\
& $(0.00)$ & & \\
$\mathrm{pH}$ & -0.32 & -0.01 & \\
& $(0.00)$ & $(0.83)$ & 0.26 \\
$\mathrm{BD}$ & -0.65 & -0.37 & $(0.00)$ \\
& $(0.00)$ & $(0.00)$ & \\
\hline
\end{tabular}

Each test is given as the Pearson correlation coefficient and $p$-value (in parenthesis).

reported in the scientific literature (Martínez et al. 2008; Deng and Shangguan 2016).

\section{Discussion}

This study reveals for the first time some physicochemical characteristics of different land use systems in the Ramsar site 2027. A great heterogeneity in SOC and STN values were found. For STN values, $68 \%$ of variability was observed; meanwhile, for SOC values, the variability was $57 \%$. The $\mathrm{pH}$ and $\mathrm{BD}$ values exhibited a lesser variability ( $10.74 \%$ and $10.50 \%$, respectively) (table 1$)$. This high variability is probably due to the land use changes from anthropogenic activities $(\mathrm{Yu}$ et al. 2012; Wang et al. 2016; Yang et al. 2016), due to which the lowest values of SOC and STN were found for HS, and RA areas. This Ramsar site has had changes in land use since 1976, when the predominant vegetation was $\mathrm{OF} / \mathrm{sSV}(20 \%)$, followed by IP (26\%), RA (37\%) and HS (1\%); unfortunately, now human settlements have grown uncontrollably, affecting the landscape drastically $(17 \%, 30 \%, 23 \%$ and $19 \%$, for $\mathrm{OF} / \mathrm{sSV}$, IP, RA and HS, respectively); and hence, it's capacity to sequester carbon. Unfortunately, there is no data on the content of carbon for previous years, which is why it is not possible to determine the decrease in the capacity of storing carbon. The effect of land use change over the capacity of capturing or sequestrating carbon has already been reported in the literature (Assefa et al. 2017; Sohng et al. 2017) and the concentration of COS has also been evaluated according to the different land uses. The total SOC stored in the analysed soils of Ramsar site is $9.67 \times 10^{5} \mathrm{t}$ during one year period, calculated by adding the SOC values in each sampling point; approximately, $40 \%$ of the total is stored by IP, followed by the OF/sSV, RA and HS $(24 \%, 23 \%$ and $13 \%$, respectively). The estimation of SOC stored in the first soil layer of $0-10 \mathrm{~cm}$ was around $56 \%\left(5.49 \times 10^{5} \mathrm{t}\right)$, higher than in the second layer $\left(4.19 \times 10^{5} \mathrm{t}\right)$, mainly due to the input of fresh litter and the higher amount of roots of the existing plants.

Soil physicochemical parameters were less correlated with each other, probably due to the variability of soils and vegetation from which soil samples were extracted; some other variables should be included to find any relationship among variables (Martínez et al. 2008). According to several reports $\mathrm{BD}$ has a close relationship with the organic carbon content in soils (Curtis and Post 1964; Perie and Ouimet 2008; Tanveera et al. 2016), and can be determined based on carbon content by empirical regressions or using logarithmic relationships for some soils (Curtis and Post 1964; Prévost 2004). In this work, a relation was found between the BD and the SOC. Such a relation shows a negative correlation coefficient of $r=-0.65 ; p<$ 0.05 and in addition, a high degree of association between both variables regarding the sampling season; in Dry 1 season, a correlation coefficient of $r=-0.58$ was observed $(p=0.00)$; on the other hand for the Rainy season, $r$ was $-0.54(p=0.00)$ and finally, for Dry 2 season, the calculated $r$ was $-0.71(p=0.00)$ (data not shown).

Reliable information of the terrestrial component of the global carbon cycle has become an issue of international concern (Bai et al. 2015). Accurate estimation of SOC stocks is necessary in order to know the carbon status and eventually to meet the requirements of the Kyoto Protocol (Vande et al. 2005). For a regional scale, SOC estimates in soils of Ramsar site 2027 are essential for the better understanding of its relevance as a carbon reservoir. In addition, appropriate SOC measures are needed to sustainably conserve Ramsar sites and therefore sustain the goods and services they provide. The soil capacity to store carbon mainly depends on the land use and management (Robert 2002). Alvarez et al. (2016) and Pérez et al. (2013) reported that the soils in oak forests can store up to $164 \mathrm{t} \mathrm{C} /$ ha and harvested stands up to $39 \mathrm{t} \mathrm{C} / \mathrm{ha}$. Comparing these data with those obtained in this work with $\mathrm{OF} / \mathrm{sSV}$ land uses of Ramsar site 2027, it can be concluded that the SOC stored $(28 \mathrm{t} \mathrm{C} / \mathrm{ha})$ is quite low, which indicates a low capacity of the areas to sequester carbon. On the other hand, induced pasture ecosystems can store up to 50-90 t C/ha (Wang et al. 2016), while in the IP area of Ramsar 
site 2027, SOC stores was 26 t $\mathrm{C} /$ ha, suggesting once again a low capacity of the site to store carbon. Finally, soils for RA of Ramsar stored 20 $\mathrm{t} \mathrm{C} / \mathrm{ha}$, which is lower than the values reported by Yang et al. (2016) and Yu et al. (2012), who reported average values of 35-46 t $\mathrm{C} /$ ha for areas with the same land use. But, this is not at all an adequate comparison because the conditions and management of the ecosystems are different; however, it is a preliminary approximation to learn about the capacity of the Ramsar site 2027 to store carbon.

\section{Conclusions}

The estimation of the current soil conditions of the Ramsar site 2027 could serve as a starting point for the development of a management plan for Ramsar sites in general with low storage capacity of carbon. The status of soils from the Ramsar site 2027 'Presa Manuel Ávila Camacho' presents a low capacity to capture carbon mainly due to land uses changes. However, this capacity may be increased by controlling human disturbance and implementing plans of sustainable management. Different authors agree that the application of soil management and conservation practices such as conservation tillage, soil retention barriers, agroforestry practices, to mention a few, favour the SOC increase up to $480 \mathrm{~kg} \mathrm{ha}^{-1} \mathrm{yr}^{-1}$ (Alvarez 2005; Scala Junior et al. 2012; Hamilton et al. 2014; Garcia et al. 2015).

\section{Acknowledgements}

The authors thank the Vicerectorate for Research and Graduate Studies (VIEP-BUAP) for the financial support offered to carry out this research. They are grateful to the Research Department of Agricultural Sciences (DICA-BUAP) for their support in conducting field trips and subsequent analysis of soil samples obtained. They also thank the Postgraduates in Environmental Sciences administrative facilities for the help in preparing this article.

\section{References}

Aliat T, Kaabeche M, Khomri H, Nouri L, Neffar S and Chenchouni H 2016 A pedological characterisation of some inland wetlands and Ramsar sites in Algeria; Land Degrad. Dev. 27 693-705.
Alvarez R 2005 A review of nitrogen fertilizer and conservation tillage effects on soil organic carbon storage; Soil Use Manag. 21(1) 38-52.

Alvarez S, Ortiz C, Díaz E and Rubio A 2016 Influence of tree species composition, thinning intensity and climate change on carbon sequestration in Mediterranean mountain forests: A case study using the CO2Fix model; Mitig. Adapt. Strateg. Glob. Change 21(7) 1045-1058.

Assefa D, Rewald B, Sandén H, Rosinger C, Abiyu A, Yitaferu B and Godbold D L 2017 Deforestation and land use strongly effect soil organic carbon and nitrogen stock in northwest Ethiopia; Catena 153 89-99.

Bai J, Wang J, Chen X, Luo G P, Shi H, Li L H and Li J L 2015 Seasonal and inter-annual variations in carbon fluxes and evapotranspiration over cotton field under drip irrigation with plastic mulch in an arid region of northwest China; J. Arid Land 7(2) 272-284.

Bao K, Zhao H, Xing W, Lu X, McLaughlin N B and Wang G 2011 Carbon accumulation in temperate wetlands of Sanjiang Plain, northeast China; Soil Sci. Soc. Am. J. 75(6) 2386-2397.

Blake G R and Hartge K H 1986 Bulk density; In: Methods of Soil Analysis (ed.) Klute A, Madison, Wisconsin 1(2) $363-375$.

Curtis R O and Post B W 1964 Estimating bulk density from organic-matter content in some Vermont forest soils; Soil Sci. Soc. Am. J. 28(2) 285.

Deng L and Shangguan Z P 2016 Afforestation drives soil carbon and nitrogen changes in China; Land Degrad. Dev. 165(1) 151-165.

Garcia N, Albaladejo J, Almagro M and Martínez M 2015 Beneficial effects of reduced tillage and green manure on soil aggregation and stabilization of organic carbon in a Mediterranean agroecosystem; Soil Tillage Res. 153 66-75.

Hamilton L, Wallis P and Leith P 2014 A review of carbon sequestration in vegetation and soils; options, opportunities and barriers for the Southern Slopes Cluster NRM's. Southern Slopes Climate Change Adaptation Research Partnership (SCARP): Victorian Department of Environment and Primary Industries.

Hobley E U and Wilson B 2016 The depth distribution of organic carbon in the soils of eastern Australia; Ecosphere 7(1) $1-21$.

Hobley E U, Baldock J and Wilson B 2016 Environmental and human influences on organic carbon fractions down the soil profile; Agric. Ecosyst. Environ. 223152 166.

Huang L, Jiyuan L, Quanqin S and Deng X 2016 Temporal and spatial patterns of carbon sequestration services for primary terrestrial ecosystems in China between 1990 and 2030; Acta Ecol. Sin. 36(13) 3891-3902.

Interdisciplinary Center for Research and Studies on Environment and Development (CIIEMAD) 2011 Partial Program of Sustainable Urban Development of Valsequillo and its Zone of Influence. Executive Version. Puebla: Secretariat of Ministry of the Environment and Natural Resources (SEMARNAT).

Jones N, McGinlay J and Dimitrakopoulos P G 2017 Improving social impact assessment of protected areas: A review of the literature and directions for future research; Environ. Impact Assess. Rev. 64 1-7. 
Juman R A and Ramsewak D 2013 Land cover changes in the Caroni Swamp Ramsar site, Trinidad (1942 and 2007): Implications for management; J. Coast. Conserv. 17(1) 133-141.

Mabwoga S and Thukral A 2014 Characterization of change in the Harike wetland, a Ramsar site in India, using landsat satellite data; Springerplus 3(1) 576.

Marques J D de O, Luizão F J, Teixeira W G, Sarrazin M, Ferreira S J F, Beldini T P and Marques E M de A 2015 Distribution of organic carbon in different soil fractions in ecosystems of central Amazonia; Rev. Bras. Ciência do Solo 39(1) 232-242.

Martínez E, Fuentes J P and Acevedo E 2008 Soil organic carbon and soil properties; J. Soil Sci. Plant Nutr. 8(1) 68-96.

McGrath D and Zhang C 2003 Spatial distribution of soil organic carbon concentrations in grassland of Ireland; Appl. Geochem. 18(10) 1629-1639.

Pal S, Manna S, Aich A, Chattopadhyay B and Mukhopadhyay S K 2014 Assessment of the spatio-temporal distribution of soil properties in East Kolkata wetland ecosystem (A Ramsar site: 1208); J. Earth Syst. Sci. 123(4) 729-740.

Pal S, Chattopadhyay B and Mukhopadhyay S K 2016 Importance of agriculture and crop residues in carbon sequestration and nutrient enrichment at agricultural farms of East Kolkata Wetland area, a Ramsar site; Curr. Sci. 110(7) 1330-1336.

Pérez S, Ramírez M I, Jaramillo P F and Bautista F 2013 Soil organic carbon content under different forest conditions: Monarch butterfly biosphere reserve, Mexico; Rev. Chapingo Ser. Ciencias For. y del Ambient. 19(1) 157-173.

Perie C and Ouimet R 2008 Organic carbon, organic matter and bulk density relationships in boreal forest soils; Can. J. Soil Sci. 88(3) 315-325.

Prévost M 2004 Predicting soil properties from organic matter content following mechanical site preparation of forest soils; Soil Sci. Soc. Am. J. 68(3) 943.

Robert M 2002 Captura de carbono en los suelos para un mejor manejo de la tierra. Estud. FAO Ser. Riego y Dren.

Sayoud M S, Salhi H, Chalabi B, Allali A, Dakki M, Qninba A and Agbani M A El et al. 2017 The first coordinated
trans-North African mid-winter waterbird census: The contribution of the International Waterbird Census to the conservation of waterbirds and wetlands at a biogeographical level; Biol. Conserv. 206 11-20.

Scala Junior, N La, Figueiredo E B de and Panosso A R 2012 A review on soil carbon accumulation due to the management change of major Brazilian agricultural activities; Braz. J. Biol. 72(3) 775-785.

Secretariat R C (ed.) 2013 The Ramsar Convention Manual: A Guide to the Convention on Wetlands; 6th edn, Gland, Switzerland.

Singh S K, Thawale P R, Sharma J K, Gautam R K, Kundargi G P and Juwarkar A A 2015 Carbon sequestration in terrestrial ecosystems; In: Hydrogen Production and Remediation of Carbon and Pollutants (eds) Lichtfouse E, Schwarzbauer J and Robert D, pp. 99-131.

Sohng J, Singhakumara B M and Ashton M S 2017 Effects on soil chemistry of tropical deforestation for agriculture and subsequent reforestation with special reference to changes in carbon and nitrogen; For. Ecol. Manag. 389 331-340.

Tanveera A, Kanth T A, Tali P A and Naikoo M 2016 Relation of soil bulk density with texture, total organic matter content and porosity in the soils of Kandi Area of Kashmir valley, India; Int. Res. J. Earth Sci. 4(1) 1-6.

Vande I, Van N, Perrin D, Lemeur R, Verheyen K, Van B and Laitat E 2005 Growing stock-based assessment of the carbon stock in the Belgian forest biomass; Ann. For. Sci. 62(4) 853-864.

Wang T, Kang F, Cheng X, Han H and Ji W 2016 Soil organic carbon and total nitrogen stocks under different land uses in a hilly ecological restoration area of North China; Soil Tillage Res. 163 176-184.

Yadav V, Malanson G P, Bekele E and Lant C 2009 Modeling watershed-scale sequestration of soil organic carbon for carbon credit programs; Appl. Geogr. 29(4) 488-500.

Yang P, Byrne J M and Yang M 2016 Spatial variability of soil magnetic susceptibility, organic carbon and total nitrogen from farmland in northern China; Catena 145 92-98.

Yu J, Wang Y, Li Y, Dong H, Zhou D, Han G and Wu H et al. 2012 Soil organic carbon storage changes in coastal wetlands of the modern Yellow River Delta from 2000 to 2009; Biogeosci. 9(6) 2325-2331. 